\title{
Clarified Plans of Military Development in the Russian Federation
}

Soon after his inauguration as President of Russia, Vladimir Putin signed a number of edicts where he specified the tasks, aims and methods of upgrading Russia's social and economic development in every sphere, including the planning of further military development in this country. Quite naturally, the edicts were addressed to officials and state bodies. Recently, Vladimir Putin has urged government ministers to timely and punctually implement these edicts. Civil society, for its part, must not stay aloof as a passive bystander. Therefore all these plans and their implementation should be subject to independent extra-departmental analysis.

No radical changes have been introduced to the structure of Russia's state bodies since Putin's inauguration as RF President. That structure has preserved its 'bifurcation', so typical of the Russian Federation. As usual, the activities of some federal bodies of executive authority (FBEA) are supervised by the RF President, while those the other FBEAs are supervised by the RF Government.

The Federal Services (FS) subordinated to the RF President include the FS for MilitaryTechnical Cooperation, the FS for Technical and Export Control (both services belong to the jurisdiction of the RF Ministry of Defense), the FS for Punishment Execution (Russia's penitentiary service), and the Federal Service of Court Bailiffs (both services belong to the jurisdiction of the RF Ministry of Justice), and the following independent services: the State Courier Service, the Federal Foreign Intelligence Service, the Federal Security Service, the Federal Protection Service, the Federal Drug Control Service, and the Federal Financial Monitoring Service. The assignment of the latter to the category of 'power services' is a novelty, which clearly testifies to the President's special interest in the issues of fiscal control and supervision.

Especially noteworthy among the Federal Agencies (FA) supervised by the RF President, are the FA for the Procurement of Armaments, Military and Special Equipment and Materiel (AMSEM), and the FA for Special Construction (both agencies are subordinated to the RF Ministry of Defense). Apart from them, the category of 'power agencies' includes the Main Directorate of Special Programs (MDSP) and the Executive Office of the RF President (both institutions are vested with the same powers as federal agencies).

However, when analyzing the plans and projects of military development, one should pay attention not only to the 'power', presidential branch of executive authority, but also to its second branch, because this division of executive power into two branches does not mean that the 'power block' is socially and economically isolated from the economic block, because these two blocks have common resources (human, material, technological, financial, etc.), and all events happening within these structures have countrywide impacts.

In many respects, this specificity of Russia's current regime is determined by this country's previous history. First of all, it is determined by the preservation of a number of 
entities organizationally isolated from the rest of Russia's economy, such as the defenseindustrial complex (DIC), the missile and space complex (FA Roskosmos), and the nuclear complex (State Corporation Rosatom). Among other things, their area of responsibility includes the task of providing Russia's armed forces with weapons and equipment. A considerable part of the RF Government's managerial functions is vested in the Military-Industrial Commission (MIC). So far, the numerous attempts at rearranging the state management system of the Russian DIC have produced unsatisfactory results. It should be noted, that as far as national security is concerned, the other FBEAs whose management and control are vested in the RF Government are also very important. These FBEAs are the FS for the State Defense Order (SDO), which exists alongside the State Armaments Program (SAP), and the FS for State Statistics (although unlike the custom adopted in many civilized states, military statistics do not actually exist in Russia). Many other FSs and FAs, which formally are not assigned to the category of 'power' structures, are also involved in national security issues.

Naturally, the question arises as to who is actually responsible for the quality of interaction between the two parts of Russia's executive authority. The relevant functions have been vested in Deputy Prime Minister Dmitry Rogozhin. In accordance with the RF President's edicts and the RF Government's resolutions, he has been instructed to 'coordinate the work of the FBEUs', and even to 'give them assignments concerning the following issues':

- ensuring the Russian Federation's national defense and mobilization readiness, and ensuring the proper management of state material reserves;

- government policy in the field of DIC development;

- execution of the SAP, the SDO and the programs of development of defense industry and the nuclear and aerospace industries;

- implementation of nuclear supervision;

- export control with regard to goods, information, work, services and the results of intellectual activities that can be used in the production of weapons of mass destruction, means of delivery of weapons of mass destruction and other types of armaments and military equipment;

- implementation of a coordinated military-technological policy within the framework of the Collective Security Treaty Organization (CSTO);

- government policy in the field of international military-technological cooperation;

- government policy in the field of civil defense and population and territories protection from emergency situations;

- development of R\&D for the purposes of implementing the goals of strategic militarytechnological and defense planning;

- development of the Russian Federation's state border infrastructure;

- elaboration of proposals concerning the creation of a system for young Russians' preparation for military service in the armed forces of the Russian Federation. 
It should be noted that the aforesaid coordination functions belong to the 'administrative resource' category. Dmitry Rogozhin has not been vested with the right to dispose of financial resources, which naturally considerably limits both his and the MIC's managerial capacities.

In his edicts on the issues of military development, the President did not condescend to give detailed instructions to individual FBEAs, confining himself instead to the formulation of his assignments to the RF Government, although the 'power block' is not subordinated thereto. In Tables 1 and 2, some of the President's assignments are followed item-by-item by our comments.

\section{RF President's Assignment Concerning Progress in Military Development}

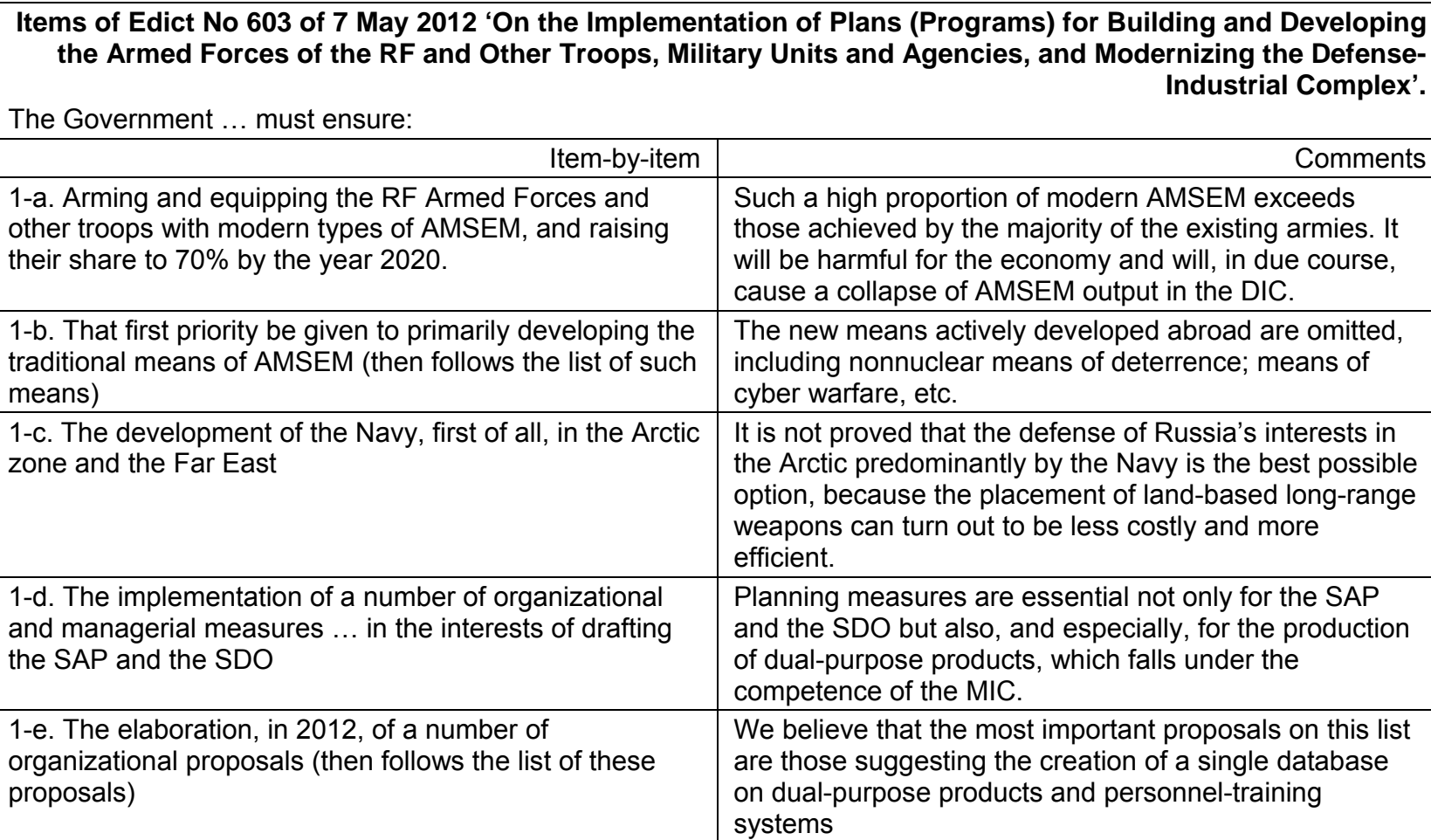

\section{The RF President's Assignment Concerning the Resolution of Problems Related to Military} Service

Items of Edict No 604 of 7 May 2012 'On Further Improvements to Military Service in the RF'. The Government ... must ensure:

1-a. The full provision, in 2013 , of housing to the military personnel of the RF Armed Forces, other troops, military units and agencies, in accordance with RF legislation. 1 -b. The creation, by 2014 , of a service housing fund.

1-c. Setting the money allowances (MA) of military personnel at levels that are no lower than the levels of pay established for workers at enterprises in the leading branches of the economy
These demands reflect the recognition that Vladimir Putin's promises to provide solution to the housing problems of servicemen have failed to materialize. At the same time and most importantly, they dilute the responsibility for resolving these problems, because both the Federal Special Construction Agency (Spetstroy) and the Housing Provision Department are subordinated not to the Government. but to the 'power' FBEAs.

It would be much more advisable if the minimum MA were tied not to some vague notions, as is done in the edict, but to the concrete countywide wage average (strictly and registered by Goskomstat), because the military organization of the State must be competitive in the open labor market. 


\begin{tabular}{|c|c|}
\hline $\begin{array}{l}\text { 1-d. An annual increase in the pensions allotted to } \\
\text { citizens dismissed from military service, by no less than } \\
2 \% \text { after adjusting for inflation. }\end{array}$ & $\begin{array}{l}\text { This demand simply reflects the previously adopted } \\
\text { norms. It fails to ensure the provision of adequate military } \\
\text { pensions to the lower tiers of the military hierarchy, i.e. to } \\
\text { former contract soldiers. }\end{array}$ \\
\hline $\begin{array}{l}\text { 1-e. An annual rise by no less than } 50 \text { thousand in the } \\
\text { number of military personnel serving under a contract, } \\
\text { over the next } 5 \text { years. }\end{array}$ & $\begin{array}{l}\text { This sentence should be clarified because some officers } \\
\text { also serve under a contract, which means that an } \\
\text { increase in their number can create an illusion that the } \\
\text { problems created by RF regular troops' switchover from } \\
\text { conscription to contract service have been solved. }\end{array}$ \\
\hline \multicolumn{2}{|l|}{ The Government must ensure in the year 2012: } \\
\hline $\begin{array}{l}\text { 2-a. The inventory auditing of the RF Armed Forces' } \\
\text { property and the subsequent transfer of social and } \\
\text { community infrastructure objects (and the responsibility } \\
\text { for financing their day-to-day maintenance) into the } \\
\text { ownership of RF subjects. }\end{array}$ & $\begin{array}{l}\text { An extremely important measure, although not fully } \\
\text { substantiated from an economic point of view. }\end{array}$ \\
\hline $\begin{array}{l}\text { 2-b. The introduction of changes to RF legislation, } \\
\text { designed to increase the prestige and attractiveness of } \\
\text { conscription military service, including through: }\end{array}$ & $\begin{array}{l}\text { The high-priority measures listed in this item of the Edict } \\
\text { can be approved, although they contradict the principle } \\
\text { of voluntary military service in time of peace. }\end{array}$ \\
\hline $\begin{array}{l}\text { - the allotment of additional benefits to former } \\
\text { servicemen seeking to enroll in higher educational } \\
\text { establishments; } \\
\text { - the allotment of grants to graduates of higher } \\
\text { educational establishments, who have completed their } \\
\text { mandatory military service, that will finance their } \\
\text { education in Russian and foreign business schools; } \\
\text { - the provision of preferential treatment to former } \\
\text { servicemen seeking for jobs in the civil service. }\end{array}$ & $\begin{array}{l}\text { Moreover, it should be taken into account when } \\
\text { implementing this Decree that, in conditions of an } \\
\text { innovative economy, education grants for former } \\
\text { servicemen should be established not only in regard to } \\
\text { business schools, but also, and maybe predominantly, in } \\
\text { regard to the educational establishments preparing } \\
\text { specialists for high-tech industries. }\end{array}$ \\
\hline $\begin{array}{l}\text { 2-c. The creation of the RF Armed Forces' national } \\
\text { reserve. }\end{array}$ & $\begin{array}{l}\text { This notion contradicts the principle that the Armed } \\
\text { Forces' reserve should be trained in the course of } \\
\text { mandatory military service; its implementation will be } \\
\text { irrationally costly, given the reputed lack of funds for the } \\
\text { switchover to contract service. }\end{array}$ \\
\hline $\begin{array}{l}\text { 2-d. Organization of work in the field of military-patriotic } \\
\text { education and physical development of the students of } \\
\text { secondary general educational establishments. }\end{array}$ & $\begin{array}{l}\text { It should be noted that both the patriotic education of } \\
\text { young people and their physical development are } \\
\text { important by no means only in regard to the military } \\
\text { sphere. They are equally important for the civil sphere } \\
\text { and the economy as a whole. }\end{array}$ \\
\hline $\begin{array}{l}\text { 2-e. The development of military-applied sports among } \\
\text { citizens of conscription age, their mastering the basics of } \\
\text { working with transport vehicles and acquiring the } \\
\text { knowledge base required by contemporary military } \\
\text { occupational specialties. }\end{array}$ & $\begin{array}{l}\text { As has been emphasized above, it will be important for } \\
\text { young people to acquire dual-use (military and civilian) } \\
\text { knowledge and skills, and to master the cutting-edge } \\
\text { information, computer and robotic technologies. }\end{array}$ \\
\hline
\end{tabular}

On the whole, the edicts under consideration are designed to make good on the promises (given by all Russian presidents since 1992) to resolve the major issues of improving Russia's defense capabilities and to provide adequate care and all types of allowances for military personnel and persons dismissed from military service.

However, judging from our past experience, no decree can guarantee that it will be duly implemented. In principle, the recent decrees can share the fate of the decrees and resolutions related to various issues of military service, issued under President Boris Yeltsin, during President Putin's first two terms in office, and under Dmitry Medvedev. It should be reminded that many aspects of military reform were doomed to failure by their inefficient managers in the FBEAs, who frequently 'cooperated' with corrupt officials and shadowy personalities - while independent no-governmental organizations exercised absolutely no control over their activities. 
Special emphasis should be placed on the planned annual increase in the number of privates and non-commissioned officers serving under a contract in the RF Armed Forces by 50 thousand, over the next five years. The failure of the Federal Target Program for the RF Armed forces' switchover to contract service in 2003-2007 indicates that the success of the new plan depends on the responsibility for its implementation being vested in an empowered official, on the openness of the personnel policy, and on society's control over the implementation of this plan. Otherwise the plan will certainly fail, given government officials' (both in uniform and in mufti) influence on Putin and their capacity to manipulate his opinion.

In corroboration of our opinion, we should quote from the Concept of the New Federal Target Program signed by Putin in his capacity as Chairman of the RF Government:

'... the switchover to mandatory military service for a term of one year means that military personnel, after their completion of training in junior specialist schools and their subsequent acquisition, in military units, of necessary practical skills in handling new-generation military equipment, will be dismissed from military service in connection with the expiry of their legislatively-established terms of mandatory military service, which means that the training of personnel will go on permanently, but there will be no fully-trained junior specialists'.

The conclusion he came to was as follows: 'The switchover to contract service is the only real way out of the current situation'.

But it did not take long for the Federal Target Program to be purged of such conclusions, not included in its approved version. And it is not by chance that the recent decree focuses not on the abolition of conscription in the regular army, but on making mandatory military service more attractive.

As far as the 'bifurcation’ of Russia’s system of government is concerned, let us mention some aspects of responsibility for military development and organization of military service in the RF Armed Forces vested in the Government of the Russian Federation:

1) As the responsibility for developing the SAP is vested in the RF Ministry of Defense and its agencies and institutions, while that for developing the SDO - in the agencies subordinated to the RF Government (the MIC and the DIC) and their institutions, this situation is fraught with tensions. This problem is a perpetual stumbling block for Russia.

2) The responsibility for manning the RF Armed Forces with conscripts is vested in the Main Organization and Mobilization Administration (GOMU) of the General Staff, while that for manning the RF Armed Forces with contract personnel - in the Main Personnel Administration of the RF Ministry of Defense. This Administration is subordinated to the RF President, while the RF Government is vested with the responsibility for changes in military service.

As far as Russian society is concerned, the Decree's proposition that the time has come for Russia to immediately begin creating a national reserve for the RF Armed Forces and other troops seems very doubtful. It can happen that Russia, the only G8 country preserving conscription to military service, will not only ignore one of the greatest achievements of civilized nations, but will recklessly borrow from them the concept of establishing and maintaining a legalized reserve, effective when a nation abolishes conscription. As a result, the combat 
efficiency of Russia's Armed Forces will not increase. Moreover, the discontent of her citizens with the situation in the armed forces will persist. Budget funds will be spent irrationally, in spite of the reputed lack of money for the creation of a fully volunteer, professional army.

The Decrees have also failed to clarify the issue of the possibilities to reduce military expenditures. Thus, the Decrees do not specify what types of AMSEM can be considered modern, and the demand that their share must be increased to $70 \%$ can be interpreted simply as the upper limit of modernization. The rest of the propositions of Decree No 603 are completely devoid of numerical expression.

As regards Decree No 604, it can be said that, for the purpose of truly prudent budget spending any surpluses, if they emerge, should be spent on accelerating the switchover of the RF Armed Forces and other troops to the method of manning all permanent combat-readiness units exclusively with contract personnel. At the same time, the numerical strength of these units should be reduced without affecting their combat efficiency. If conscription is to be preserved, its purpose should be limited to preparing personnel for contract military service and for their inclusion in the adequately trained military reserve.

Maybe, Russia has some secret documents that contain answers to the questions posed by society and independent experts. However, judging by the adjustments being made to the projects published in 2008 by Chief of the RF General Staff Nikolai Makarov in the course of the RF Armed Forces ‘transition to a new image' masterminded by him, this 'new image' was rather vague. That is why it was subject to many serious impromptu alterations.

Both society and the President have reasons for concern. The President's remarks at a cabinet meeting devoted to the draft federal budget for 2013-2015 is very typical in this respect ${ }^{1}$ : 'I would like to say a few words about those executive orders. We have said many times, and I warned from the very beginning that those executive orders must not remain on paper. They should be reflected in the practical efforts of the cabinet of ministers - the Government of the Russian Federation. I have talked about this many times with almost everyone present here, as well as with those who are absent today. After all, the majority of people in our country are closely monitoring the domestic political situation and the plans announced by the country's leadership, and they are waiting for us to implement the tasks set out in those executive orders. We cannot allow a situation when the executive orders and the major, fundamental goals they set are one thing, and the activities of the executive branch are another. We must not and will not allow this, I say this straight away'.

At the same time, people see not only that the plans are clumsily implemented. They also see the continuation of officials' fighting for real powers and for having their say in the use of budget funds. Recently, the RF Minister of Defense has redistributed the functions of his deputies $^{2}$ : his first deputy, Alexander Sukhorukov (a tank man by education, better known as lieutenant colonel of the FSB), who had supervised the implementation of the SDE, has handed over that responsibility to another deputy minister, Dmitry Chushkin, who is also known not as a specialist in AMSEM issues. According to available information, he is more competent in

\footnotetext{
${ }^{1}$ Kremlin.ru/news/6493.

${ }^{2}$ Kommersant. No 193. 13 October 2012.
} 
information and financial issues. The questions as to why authentic armament specialists are still deprived of any real influence on the development of AMSEM, and how the recent redistribution of managerial functions will help properly rearm the RF Armed Forces, have so far remained unanswered. 